\title{
The Lived Experience: A Study In Teaching Online
}

Bobbette M. Morgan, The University of Texas Rio Grande Valley, USA

\begin{abstract}
A researcher with five years' experience of teaching online classes shares what she has seen and experienced while working with her students. Through the evolution of working with Tegrity, Collaborate, and ZOOM the author shares the lived experience. The work of Max van Manen, a phenomenological researcher, serves as the framework. Descriptions are included of experiences from actual online classes. Research supports the findings: communication is essential in online classes; establishing a community of learners provides support to all involved; and students need to be accountable to themselves, the class and to the professors.
\end{abstract}

Keywords: Online Learning; Lived Experience; Community of Learners; Phenomenology

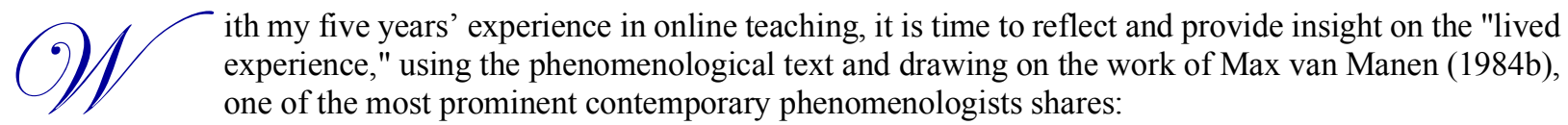

The increasing bureaucratization of pedagogic institutions and technologizing effect of educational research and knowledge forms tend to erode our understanding and praxis of pedagogic competence in everyday life. It is in this sense that phenomenological research has radical consequences... Phenomenology responds to the need for theory of the unique...It is thoughtful learning which is at the heart of our pedagogic competence. (p. 19)

Teaching online classes at the graduate level, for me, began with using Tegrity, taping face-to-face classes for those students unable to attend, so they may watch the sessions later and/or made available to all for review. That was 2008. I moved to using Collaborate in 2012 with my first all on-line course. I was able to see only one student at a time and could respond to questions through a chat feature or through microphones or headsets. The bandwidth was a problem on busy evenings: students told me I sounded like a chipmunk. Trying to correct this, I went through three headsets on the advice of the instructional technology (IT) advisors, each headset more expensive than the last. Finally, one of the IT support people said it was bandwidth and the headsets did not really make a difference. He was correct. I did not care for the Collaborate format because I could not "see" all the other students. I felt disconnected and was not able to establish a learning community. Students did well and passed the course based on work submitted and provided with additional feedback and online support, but I was not enjoying the experience. In an article about a first time online instructor's experience by Choi \& Park (2006), the instructor had trouble in communicating with and interacting with students. In addition, because she experienced student apathy during class sessions, she had to create new teaching materials to facilitate students' interaction and participation. Her experiences illustrate what many scholars have contended: that interactive communication and facilitation are critical factors in accomplishing successful online teaching (e.g., Moore, 1989; Moore \& Kearsley, 2005; Williams, 2003). Therefore, an online instructor, particularly a novice instructor, should be aware of the importance of communication and interaction with students and thus prepare for enhanced facilitation during course planning (Choi \& Park, 2006).

The summer of 2015, I shifted to what I am currently using, ZOOM.US, which provides the opportunity to see everyone all at once: we look like "the Brady Bunch." I can call on students randomly and put small groups of 2-3 students in separate rooms for cooperative group activities that I can visit and monitor. The students and I can share our screens. This enables everyone to view and share PowerPoints, charts, journal articles, or anything that can be put on computer desktops. This has made all the difference in how I feel about teaching online. Now I know my students, 
recognize them, be familiar with their writing and interests, and feel as though I have learned as much about them as they have about our course topics. A true learning community develops as we get to know everyone in the class.

Communities, whether they are learning, practice, or inquiry involve key distinct features such as sense of shared purpose, establishment of boundaries defining who is a member and who is not, establishment of rules/policies regarding community behavior, continuous interaction, and a level of trust, respect, and support among community members (Vessely, Bloom \& Sherlock, 2007). Glazer and Wanstreet (2011) suggested that another key distinct feature is that of connectedness with interconnected activities being characteristic of a close interactional environment.

A key aspect of this online teaching is the sense of community and how these communities develop within the confines of online instruction (Costello \&Welch, 2014).

There is an expectation that all the students must do their fair share, support their peers, and be prepared to discuss topics for the day. I encountered many surprises, frustrations, and moments of high anxiety along the way. I will share these "lived experiences" through a modified outline:

\section{Van Maren's Outline for Conducting Phenomenological Research (modified)*}
A. Turning to the Nature of Lived Experience
1. Orienting to the phenomenon
B. Existential Investigations
1. Exploring the phenomenon: generating "data"
a. Using personal experience as a starting point
C. Phenomenological Reflection
1. Conducting thematic analysis
a. Uncovering thematic aspects in lifeworld description
2. Determining essential themes
D. Phenomenological Writing
1. Attending to the speaking of language
2. Varying the examples
3. Writing
4. Rewriting: (A) to (D), etc. (van Manen, 184b).

Thirty-two percent of students at U. S. colleges and universities are enrolled in at least one online course (Allen \& Seaman, 2013). In order to teach a summer online course all faculty at my university had to take and pass a Quality Matters course. Quality Matters (QM) provides a peer review process designed to certify the quality of online courses (Quality Matters, 2014). Initially developed under a federally funded grant, Quality Matters is an independent organization with 900 subscribing educational institutions. The QM Program is a leader in quality assurance for online education. The QM rubric is based on nationally recognized standards of best practice, research literature, and quality assurance standards for online course design (Shattuck, 2007).

During the summer of 2015 I taught my first ZOOM doctoral level class with three students. One student was in Abilene, Texas more than 700 miles from campus. His class space at home was the family room. His two large dogs would "visit" once and a while. This occurred especially if the student had a sandwich close by and the dogs were looking for a snack. Barking was added to our classroom sounds.

The other two students, also male, logged in from home offices with quiet backgrounds. Overall, I enjoyed seeing the students, facilitating discussions, and decided to try ZOOM with a larger group. Students were extremely positive about the ZOOM format. It was the first time they had been exposed to it also.

Fall of 2015 I had two doctoral classes online with about 15 students in each class. These were two sections of the same class. From the first night unusual things began to happen. I suddenly realized that I was invading their home space. They did not have experience of the professor showing as soon as they connect. I was an intruder. The students 
were not accustomed to having the Professor and all their classmates "pop" into their space the moment they logged in. Many were surprised, embarrassed, or uncertain if they were in the correct class.

Students joined class from kitchens, bedrooms, living rooms, attics, on top of ladders, in parked cars having dinner, and in moving vehicles. I never thought I would need to talk to students about driving while in class, drinking in class, dressing appropriately, or not while you are working (retrieving a beehive from an apartment building while on a ladder). Twenty first century learning is opening us all up to new and unusual learning environments and experiences. In a paper by Simone C. O. Conceicao (2006), she states that teaching and learning become a partnership resulting from learner-centered environments. She continues that these environments are not controllable and predictable; they require faculty members to think about themselves very differently as instructors, recognize the changes in the educational paradigm, engage in new kinds of activities, and reconsider the meaning of being and expert.

How should I expect them to dress? Why am I surprised that they sign-in to class in pajamas, workout clothes, shorts, or business attire?

\section{NOT Clothing Optional}

When one student logged in, she was seated at a table in her living-room, scantily dressed in bra and shorts. She looked at her screen and realized she could see all members of the class and that we could see her. She looked startled but did not say anything. She just got up, left the room, and returned a few minutes later with a blouse added to her attire and sat down as we began class.

\section{Zumba!}

Another student logged in from her iPhone. The class could see her, but she had not used ZOOM before so did not know we could see her. Lively music was playing. We could see a Zumba class dancing in the background and she was in workout clothes. She was trying to position the iPhone on a shelf at the front of the room so she could be "signed-on" and participate in Zumba.

I spoke up, said hello to her, and called her by name. She looked startled, gathered up belongings, and keeping the phone in her hand took us to the car, drove us to her home, and participated in class. That was the end of Zumba on our class nights.

I had heard of students logging into classes while being in another class or going off to do other things, but thought not my class! Choi and Park, (2006) in the Quarterly Review of Distance Education had a student share, "I was taking the online class, and my children had a big fight. At that time, I had to intervene. As a result, I missed half of the class...In addition my peer confessed that she watched her favorite TV show during class. That is a big secret, I usually used the class time when I need to post the assignments and should be participating in the team discussion.

\section{Dancing Boxers}

One young woman, who was a very serious student, logged on from her kitchen. We could see that she was at the table with all of her materials and resources, ready to participate in class. Everything was neat and orderly.

On the first night of class, about halfway through, her husband danced across the room behind her. He went to the refrigerator for a bottled beverage and danced back---all the while in only his boxers waving at us behind her. Everyone could see this, but no one said anything. This was repeated most weeks of the semester. No one said anything, but everyone saw him, week after week. Doesn't he have a right, in his own home, to get a drink from the refrigerator? What does this say about us as a class? Are we all voyeurs? 


\section{The "Bee Man"}

That is what I now refer to him as. The first night of class I ask the students to take a couple of minutes and introduce themselves. He took us to a YouTube clip of him in just a pair of white shorts holding a Queen Bee he has taken from a hive he was moving to a new location. As the clip plays we see him become covered in more than 75,000 live bees! They are everywhere! They covered his face, head, chest, arms, and stomach.

Over the next sixteen weeks we saw him removing hives from apartment buildings while standing on a 20 foot ladder with the Iphone propped in his truck window so we could see him. He signed into class while driving a semi flatbed truck to North Dakota to pick up his hives before winter. We were shown collapsed hives and healthy hives via ZOOM, learned about the jobs bees have at different stages of their development, and how he maintains the hives and gets them ready to travel to California to fertilize the almond crops later in the winter.

After two weeks, I thought I would decrease the amount of time on non-class topics, but found that his classmates were curious and asking questions, so each week we learned a little more about bees.

\section{Driving while Participating in Class}

This occurred more often than one might think. I finally had to enforce the rule that students can participate in class if someone else is driving. This was acceptable to students. They have logged in from moving vehicles in Key West, Florida while traveling with Boy Scouts; from Maine while on a summer vacation with family; from North Dakota while participating in a teacher professional development conference and while driving home to Texas from California after a quick trip to check on a teenage daughter, who ended up in the hospital after being hurt building a human pyramid at Stanford.

\section{Drinking while in Class}

During a final exam one student, laying on the couch with his "drink" in his hand tried to participate in an oral exam. I do not advise this. It was a very bad choice. Now I discuss this in advance of all exams as things not to do. Clarity and articulation are important skills to possess during an exam. Enough said.

\section{Meeting the Family (Including the Cats and Dogs)}

Over the semester, entire classes have been introduced children, spouses, houseguests, relatives, cats, dogs, hamsters, guinea pigs, lizards, turtles, and Teddy Bears. Pretty much, anyone that comes by is introduced to the class. Students enjoy learning about each other and about each other's families.

\section{SUMMARY}

Curriculum is to be thought of...as meaning and as lived in (John Steven Mann, 1975, p. 147 as cited in Pinar, Reynolds, Slattery, \& Taubman, 2008).

Through the research and the experiences shared, it is clear that communication is essential, establishing a community of learners provides support to all involved, and students need to be accountable to themselves, the class and to the professor. Savery and Duff (1995) contend that the active engagement of students in discourse during analysis of complex problems prompts learning through comparative mental processes and enriches application of content to other problem-solving circumstances. The quality of interaction and engagement between instructor and students is related to both.

Understanding the lived experience through the phenomenological approach enriches our perspective. Crotty (1998) noted Phenomenology is an attempt to gain an in-depth understanding of the human experience. Van Manen's outline provides a structure that promotes understanding of the "lived experience." 


\section{AUTHOR BIOGRAPHY}

Bobbette M. Morgan, Ed. D. is a Professor in the Teaching and Learning Department of the College of Education and P-16 Integration at The University of Texas Rio Grande Valley. She is located at the Brownsville, Texas campus. Correspondence concerning this article should be addressed to Bobbette M. Morgan, Teaching and Learning Department, UTRGV, One West University Blvd., Brownsville, TX 78520-4933.

E-mail: bobbette.morgan@utrgv.edu

\section{REFERENCES}

Allen, I. E. \& Seaman, J. (2013). Changing course: Ten years of tracking online education in the United States. Babson Survey Research Group and Quahog Research Group. San Francisco, CA. Retrieved June 3, 2015 from: $\mathrm{http} / / / \mathrm{www}$. onlinelearningsurvey.com/reports/changingcourse.pdf

Choi, H. J. \& Park, J. H. (2006). Difficulties that a novice online instructor faced: A case study. Quarterly Review of Distance Education, 7(3), 317-322.

Conceicao, S. (2006). Faculty lived experiences in the online environment. Adult Education Quarterly, 57(1), 26-45.

Costello, R. \& Welch, S. A. (2014). A qualitative analysis of faculty and student perceptions of effective online class communities using Herzberg's motivator-hygiene factors. Quarterly Review of Distance Education, 15(4), 15-24.

Crotty, M. (1998). The foundations of social research: Meanings and perspective in the research process. Thousand Oaks, CA: Sage Publications.

Glazer, H. R. \& Wanstreet, C. E. (2011). Connection to the academic community: Perceptions of students in online education. The Quarterly Review of Distance Education, 12(1), 55-62.

Mann, J. S. (1975). In Pinar,W. F., Reynolds, W. M., Slattery, P., and Taubman, P. M. (2008). Understanding curriculum: An introduction to the study of historical and contemporary curriculum discourses. Peter Lang: New York, NY.

Moore, M. G. (1989). Three types of interaction. The American Journal of Distance Education, 3(1), 1-6.

Moore, M. G. \& Kearsley, G. (2005). Distance education: A systems view (2ned ed.). Belmont, CA: Wadsworth.

Pinar, W. F., Reynolds, W. M., Slattery, P., and Taubman, P. M. (2008). Understanding curriculum: An introduction to the study of historical and contemporary curriculum discourses. Chapter 8, pp. 404-449, Peter Lang: New York, NY.

Quality Matters Higher Education-Subscriptions (2014). Annapolis, MD: Maryland Online. Retrieved June 4, 2015 from: https://www.qualitymatters.org/subscriptions

Shattuck, K. (2007). Quality matters: Collaborative program planning at a state level. Online Journal of Distance Learning Administration, 10(3). Retrieved from: http://www.westga.edu/ distance/ojdla/fall103/shattuck103.htm

Savery, J. \& Duffy, T. (1995). Problem based learning: An instructional model and its constructivistic framework. Educational Technology, 35, 31-38.

Vessely, P., Bloom, L. \& Sherlock, J. (2007). Key elements of building online community: Comparing faculty and student perceptions. Journal of Online Learning and Teaching, 3(3), 1-12.

Williams, P. E. (2003). Roles and competencies for distance education programs in higher education institutions. The American Journal of Distance Education, 17(1), 45-57. 
NOTES 